\title{
Perbedaan $\beta$-crosslaps Serum Penderita Karsinoma Payudara Pascamenopause antara yang Diberikan Anastrozol dan Tamoksifen
}

\author{
Randy Sebastian, ${ }^{1}$ Maman Abdurahman, ${ }^{2}$ Kiki A. Rizki ${ }^{3}$ \\ ${ }^{1}$ Rumah Sakit Ridogalih Sukabumi, ${ }^{2}$ Divisi Bedah Onkologi Kepala Dan Leher Departemen Ilmu Bedah Fakultas \\ Kedokteran Universitas Padjadjaran/Rumah Sakit Dr. Hasan Sadikin Bandung
}

\begin{abstract}
Abstrak
Tamoksifen dan inhibitor aromatase sebagai terapi adjuvan memiliki peranan penting pada karsinoma payudara (KPD) pascamenopause dengan reseptor estrogen positif. Saat ini inhibitor aromatase dapat menggantikan tamoksifen karena memiliki keuntungan yang lebih baik dibanding dengan tamoksifen. Inhibitor aromatase juga memiliki efek samping meningkatkan penyerapan tulang yang memicu osteoporosis dan fraktur dibanding dengan tamoksifen. Saat terjadi proses penyerapan tulang, matriks tulang yang $90 \%$ terdiri atas kolagen tipe I akan terurai sehingga salah satu hasil penguraiannya berupa $\beta$-CrossLaps terdapat dalam darah dan dapat diukur kadarnya. Penelitian ini mengukur perbedaan kadar $\beta$-CrossLaps serum baik pada pasien KPD pascamenopause yang diberikan anastrozol dan tamoksifen di Rumah Sakit Dr. Hasan Sadikin Bandung periode Januari-Juli 2013. Penelitian ini merupakan penelitian potong lintang. Terdapat 32 pasien, yaitu 16 pasien tiap kelompok. Hasil pengolahan data statistik dengan derajat kepercayaan 95\% menunjukkan perbedaan yang bermakna kadar $\beta$-CrossLaps serum KPD yang diberikan anastrozol dibanding dengan yang diberikan tamoksifen $(\mathrm{p}<0,05)$. Simpulan, kadar $\beta$-CrossLaps rata-rata serum KPD yang diberikan anastrozol lebih tinggi dibanding dengan tamoksifen, artinya pemberian obat anastrozol pada pasien KPD pascamenopause dalam jangka waktu $>6$ bulan meningkatan proses penyerapan tulang dibanding dengan yang diberikan tamoksifen. [MKB. 2015;47(4):207-11]
\end{abstract}

Kata kunci: Anastrozol, $\beta$-CrossLaps serum, tamoksifen

\section{Comparison of $\beta$-crosslaps Serum Levels between Postmenopausal Breast Carcinoma Patients Receiving Anastrozol and Tamoxifen}

\begin{abstract}
Tamoxifen and inhibitor aromatases as adjuvant therapy plays an important role in postmenopausal breast cancer patients with positive estrogen receptor. Currently, inhibitor aromatases can replace tamoxifen because it has more advantages than tamoxifen. Inhibitor aromatases also have side effects which is increased bone resorption that triggers osteoporosis and fractures when compared to tamoxifen. During the process of bone resorption, bone matrix, composed of $90 \%$ type I collagen, were broken down resulting in $\beta$-crosslaps content in the blood, which is measurable. This study measured the levels of serum $\beta$-crosslaps in postmenopausal breast cancer patients who received anastrozol and tamoxifen in Dr. Hasan Sadikin General Hospital Bandung between January and July 2013. This was a cross-sectional study with comparative analytics to compare the mean levels of serum $\beta$-crosslaps in postmenopausal breast cancer patients between the two groups. There were 32 patients in this study, 16 patients in each group. The results of data processing using statistical tests at $95 \%$ confidence level revealed that there was significant differences in serum levels of $\beta$-crosslaps between the group who received anastrozol and those who received tamoxifen $(\mathrm{p}<0.05)$. In conclusion, the mean value of $\beta$-crosslaps serum in anastrozol group is higher than in tamoxifen group. This means that postmenopausal breast cancer patients receiving anastrozol for more than 6 months could may experienced a higher degree of bone resorption compared to those receiving tamoxifen. [MKB. 2015;47(4):207-11]
\end{abstract}

Key words: Anastrozol, serum $\beta$-crosslaps, tamoxifen

Korespondensi: Randy Sebastian, dr., Sp.B, Rumah Sakit Ridogalih Sukabumi, Jalan Ridogalih No. 24, Kecamatan Sukabumi, Jawa Barat, Telepon (0266) 221983, mobile 081221547427,e-mail sebastianrandy@yahoo.co.id 


\section{Pendahuluan}

Karsinoma payudara (KPD) adalah karsinoma pada wanita dengan frekuensi paling tinggi di dunia. ${ }^{1}$ Di Amerika Serikat pada tahun 2011 diperkirakan terdapat 230.480 kasus baru KPD invasif pada wanita, menempatkan KPD sebagai kasus karsinoma terbanyak setelah kanker paru dan bronkus. ${ }^{1}$ Terapi hormonal sebagai terapi adjuvan yang mempunyai peranan penting pada KPD pascamenopause dengan hormon reseptor positif. Saat ini dikenal dua jenis obat yang dipergunakan untukterapi hormonal pada pasien karsinoma payudara pascamenopause, yaitu tamoksifen dan inhibitor aromatase. Tamoksifen sudah menjadi terapi standar sebagai terapi adjuvan pada KPD dengan hormon reseptor positif, yaitu estrogen reseptor dan progesteron reseptor yang positif. Penggunaan tamoksifen selama 5 (lima) tahun dapat mengurangi angka rekurensi 47\% dan angka kematian 26\%. ${ }^{1,2}$

Pada saat ini inhibitor aromatase mampu menggantikan tamoksifen karena mempunyai beberapa kelebihan, yaitu mampu mengurangi angka rekurensi dan angka kematian, masa bebas kanker yang lebih lama, dan mengurangi angka terjadinya karsinoma payudara kontralateral yang lebih baik dibanding dengan tamoksifen. ${ }^{3}$ Penelitian Cuzick $^{4}$ menyatakan angka kejadian kanker endometrium, tromboemboli vena, dan perdarahan per vaginam tersebut lebih sedikit pada pasien karsinoma payudara yang diberikan anastrozol dibanding dengan tamoksifen.

Di samping keuntungan pemberian inhibitor aromatase, inhibitor aromatase juga mempunyai efek samping. Salah satu efek samping, yaitu mamapu meningkatkan penyerapan tulang. Dari penelitian yang sudah dilakukan sebelumnya, angka kejadian osteoporosis dan fraktur juga meningkat pada pasien yang diberikan inhibitor aromatase dibanding dengan tamoksifen. ${ }^{4,5}$

Penelitian yang dilakukan Howell dan Locker ${ }^{6}$ menyatakan bahwa angka kejadian fraktur pada pasien yang diberikan inhibitor aromatase jenis anastrozol lebih tinggi dibanding dengan tamoksifen, yaitu $21,55 \%$ berbanding $13,44 \%$. Penelitian yang dilakukan oleh Eastell dkk. ${ }^{7}$ menyatakan bahwa setelah pemakaian inhibitor aromatase jenis anastrozol selama dua tahun terjadi penurunan kepadatan tulang yang diukur dengan densitometri, yaitu $4 \%$ pada tulang lumbal dan 3,2\% pada tulang panggul. Penelitian yang dilakukan oleh Goss dkk. ${ }^{8}$ melaporkan bahwa penggunaan anastrozol tersebut mampu meningkatkan angka kejadian osteoporosis, yaitu $5,8 \%$ dibanding dengan plasebo $4,5 \%$. Penelitian yang dilakukan oleh Lonning ${ }^{9}$ juga menyatakan hal yang sama. Penelitian yang dilakukan Dowsett dkk. ${ }^{10}$ menyatakan tidak akan terjadi peningkatan osteoporosis yang signifikan pada pasien yang diberikan inhibitor aromatase jenis eksemestan bila dibanding dengan tamoksifen, yaitu $7,4 \%$ dengan $5,7 \%$.

Saat ini telah ditemukan beberapa penanda penyerapan tulang, salah satunya cross-linked C-terminal telopeptide of type I collagen (CTX) yang terdiriatas $\alpha$-CrossLaps dan $\beta$-Crosslapsyang merupakan penanda penyerapan tulang yang cukup sensitif dan spesifik dibanding dengan penanda lainnya. Pemeriksaan $\beta$-Crosslaps ini memiliki nilai sensitivitas $89 \%$ dan spesifisitas lebih dari $80 \%{ }^{3}$ Saat ini yang tersedia secara komersiil di Rumah Sakit Dr. Hasan Sadikin (RSHS) Bandung, yaitu pemeriksaan kadar $\beta$ Crosslaps serum..$^{11,12}$

Berdasarkan penelitian Szulc dan Delmas ${ }^{12}$ dilaporkan bahwa pemeriksaan penanda pada penyerapan tulang mampu mendeteksi lebih awal perubahan pergantian tulang dibanding dengan pemeriksaan densitometri pada kasus osteoporosis. Penelitian tersebut menyatakan bahwa pemeriksaan pada kadar $\beta$-Crosslaps serum secara klinis lebih bermanfaat di dalam mendeteksi penyerapan tulang karena tingkat sensitivitas dan spesifisitas yang lebih tinggi. Penelitian lainnya, yaitu penelitian Cepelak dan Cvoriscec ${ }^{13}$ menyatakan bahwa dengan memakai densitometri perubahan massa tulang baru dapat terdeteksi setelah kurang lebih satu tahun, tetapi dengan pemeriksaan $\beta$-Crosslaps dapat terdeteksi dalam waktu kurang lebih tiga bulan. Pemeriksaan penanda tulang $\beta$-Crosslaps serum bersifat noninvasif dengan biaya lebih murah bila dibanding dengan pemeriksaan densitometri, ataupun sidik tulang, dan dapat diulang sesuai dengan kepentingan klinis sehingga mampu mendeteksi dini penurunan massa tulang.

\section{Metode}

Penelitian dilakukan di Divisi Bedah Onkologi, Kepala dan Leher, Departemen Ilmu Bedah Fakultas Kedokteran Universitas Padjadjaran/ RSHS Bandung dan Departemen Patologi Klinik Fakultas Kedokteran Universitas Padjadjaran/ RSHS Bandung. Penelitian ini berlangsung pada Januari-Juli 2013.

Penelitian ini menggunakan objek penelitian berupa darah vena yang berasal dari tubuh penderita sehingga penelitian ini dilaksanakan setelah mendapatkan persetujuan Departemen 
Patologi Anatomi (PA) Fakultas Kedokteran Universitas Padjadjaran/Rumah Sakit Dr. Hasan Sadikin Bandung dan rekomendasi dari Komite Etik Penelitian Kesehatan Fakultas Kedokteran Universitas Padjadjaran/RSHS Bandung, Nomor: 141/UN6.C2.1.2/KEPK/PN/2013.

Penelitian ini merupakan penelitian potong lintang membandingkan kadar $\beta$-Crosslaps ratarata pada kedua kelompok. Subjek penelitian adalah pasien wanita dengan diagnosis KPD pascamenopause yang diberikan anastrozol dan yang diberikan tamoksifen di RSHS Bandung yang memenuhi kriteria inklusi serta bersedia dan setuju untuk mengikuti penelitian. Kriteria inklusi adalah pasien wanita dengan diagnosis KPD pascamenopause yang sudah diberikan anastrozol dan juga tamoksifen antara 6 bulan sampai 1 tahun dan belum pernah mendapat terapi obat dengan golongan bisfosfonat. Kriteria eksklusi adalah pasien wanita dengan diagnosis KPD pascamenopause yang sudah diberikan anastrozol ataupun tamoksifen yang sudah mengalami metastasis tulang dan osteoporosis.

Pada penelitian ini ukuran sampel ditentukan mempergunakan formula uji hipotesis dua ratarata sehingga didapatkan besar sampel minimal untuk tiap kelompok adalah 12 subjek. Diagnosis KPD ditegakkan dengan melakukan anamnesis, pemeriksaan klinis, lalu dilakukan biopsi insisi serta pemeriksaan penunjang untuk menentukan staging (foto toraks posisi posteroanterior, ultrasonografi hati, dan sidik tulang). Jaringan tumor hasil biopsi insisi diperiksa patologi di Departemen Patologi Anatomi FK Universitas Padjadjaran/RSHS Bandung dengan pewarnaan hematoksilin eosin (HE) untuk mengetahui jenis histopatologis tumor. Langkah selanjutnya yaitu pengambilan sampel darah vena sebanyak $3 \mathrm{~mL}$ untuk pemeriksaan kadar $\beta$-Crosslaps serum di Laboratorium Patologi Klinik RSHS Bandung. Sediaan darah vena sebanyak $3 \mathrm{~mL}$ disentrifugasi $2.000 \mathrm{x} /$ menit selama 10 menit dan juga cairan supernatan dipisahkan sebagai sampel. Setelah itu diambil sebanyak $50 \mu \mathrm{L}$ sampel, dicampur dengan biotinylated monoclonal anti- $\beta$-Crosslaps antibody, lalu diinkubasi. Langkah selanjutnya, yaitu ditambahkan dengan streptavidin-coated microparticles dan monoclonal anti- $\beta$-Crosslapsspesific antibody yang telah dilabelisasi dengan ruthenium complex. Kompleks ini akan berikatan melalui interaksi biotin dan juga streptavidin. Campuran yang sudah dikerjakan lalu diaspirasi dan dilakukan pengukuran hasil dengan alat Elecsys 2010/Cobas E411.

Setelah semua data terkumpul, lalu data diolah secara komputerisasi untuk mengubah data menjadi informasi. Sebelum dilakukan analisis bivariat dilakukan terlebih dahulu uji normalitas data numerik, yaitu terhadap kadar $\beta$-Crosslaps serum baik pada pasien KPD yang diberikan anastrozol maupun pada pasien KPD yang diberikan tamoksifen Uji Shapiro Wilk untuk besar sampel $<50$ orang. Data berdistribusi normal bila $\mathrm{p}>0,05$.

Setelah dilaksanakan uji normalitas data, lalu dianalisis bivariat untuk dapat membandingkan kadar $\beta$-Crosslaps serum antara pasien KPD yang diberikan anastrozol dan yang diberikan tamoksifen dengan uji parametrik, yaitu nilai uji-t independent apabila data kadar $\beta$-Crosslaps serum berdistribusi normal dan digunakan Uji Nonparametrik Mann Whitney bila data kadar $\beta$-Crosslaps serum tidak berdistribusi normal.

\section{Hasil}

Penelitian ini memasukkan 16 pasien untuk setiap kelompok. Sebelum dilakukan uji statistik terhadap perbedaan antara kadar $\beta$-Crosslaps serum rata-rata pada kedua kelompok, dilakukan penilaian uji normalitas data untuk data numerik dengan jumlah subjek penelitian $<50$, uji yang dipergunakan adalah Uji Normalitas Shapiro Wilk.

Berdasarkan atas hasil penelitian didapatkan $p=0,25$ untuk pasien KPD yang diberi tamoksifen dan untuk pasien KPD yang diberikan anastrozol didapatkan $p=0,002$. Nilai probabilitas tersebut lebih rendah daripada nilai alpha $(\mathrm{p}<0,05)$ maka dapat disimpulkan bahwa kelompok data berdistribusi tidak normal. Uji Mann Whitney digunakan untuk dapat mengetahui perbedaan kadar $\beta$-Crosslaps serum rata-rata antara dua kelompok distribusi, oleh karena data yang tidak normal.

Diketahui bahwa kadar $\beta$-Crosslaps ratarata pada kelompok pasien KPD yang diberikan anastrozol sebesar 0,488 dengan kadar terendah $0,340 \mathrm{ng} / \mathrm{mL}$ dan tertinggi $0,965 \mathrm{ng} / \mathrm{mL}$ dengan simpangan baku sebesar 0,173 , sedangkan kadar $\beta$-Crosslaps rata-rata pada kelompok pasien KPD yang diberikan tamoksifen sebesar 0,216 dengan kadar terendah 0,101 ng/mL dan tertinggi 0,415 $\mathrm{ng} / \mathrm{mL}$ dengan simpangan baku sebesar 0,076 (Tabel).

Kadar $\beta$-Crosslaps rata-rata pada kelompok pasien KPD yang diberikan anastrozol lebih tinggi bila dibanding dengan kadar $\beta$-Crosslaps kelompok pasien KPD yang sudah diberikan tamoksifen. Dari hasil analisis statistik pada derajat kepercayaan 95\% menunjukkan bahwa 
Randy: Perbedaan $\beta$-crosslaps Serum Penderita Karsinoma Payudara Pascamenopause antara yang Diberikan Anastrozol

Tabel Perbedaan Kadar $\beta$-Crosslaps Serum Kanker Payudara antara Anastrozol dan Tamoksifen

\begin{tabular}{lccc}
\hline $\begin{array}{c}\text { Kadar } \boldsymbol{\beta} \text {-CrossLaps } \\
\text { serum (ng/mL) }\end{array}$ & $\begin{array}{c}\text { KPD yang Diberi Tamoksifen } \\
(\mathbf{n = 1 6 )}\end{array}$ & $\begin{array}{c}\text { KPD yang Diberi Anastrozol } \\
(\mathbf{n = 1 6 )}\end{array}$ & $\mathbf{p}$ \\
\hline Rata-rata (SB) & $0,216(0,076)$ & $0,488(0,173)$ & $<0,05$ \\
Median (Rentang) & $0,210(0,101-0,415)$ & $0,445(0,340-0,965)$ & \\
\hline
\end{tabular}

perbedaan kadar $\beta$-Crosslaps rata-rata serum antara kedua kelompok tersebut signifikan.

\section{Pembahasan}

Proses penyerapan tulang akan menguraikan matriks tulang sehingga komponen-komponen yang terkandung di dalamnya larut dalam darah untuk kemudian diekskresi melalui ginjal. Salah satu komponen matriks tulang yang terurai dan dapat diidentifikasi kadarnya dari serum adalah fragmen dari CTX, yaitu $\beta$-Crosslaps. Maka, proses penyerapan tulang akan meningkatkan kadar $\beta$-Crosslaps serum. Hasil penelitian ini sesuai dengan teori tersebut yang menyatakan bahwa kadar $\beta$-Crosslaps rata-rata serum pada KPD yang diberikan anastrozol lebih tinggi secara signifikan dibandingdengan kadar $\beta$-Crosslaps serum rata-rata pada KPD yang telah diberikan tamoksifen. . $^{14,15}$

Penelitian ini juga sesuai dengan hasil dari penelitian Baum dkk. ${ }^{3}$ yang menyatakan pada grup yang diberikan anastrozol, efek terhadap muskuloskeletal dan juga fraktur lebih besar, terutama pada tulang belakang, panggul, dan pergelangan tangan. Insidensi fraktur lebih tinggi, yaitu $11 \%$ dibanding dengan yang diberikan tamoksifen, hanya 7,7\%. Dari penelitian tersebut dinyatakan terjadi penurunan densitas massa tulang sebanyak $2 \%, 4 \%$, dan $6 \%$ pada tulang lumbal, serta $1,5 \%, 3,9 \%$, dan $7,2 \%$ pada tulang panggul setelah penggunaan selama 1, 2, dan 5 tahun. Dari penelitian lainnya yaitu penelitian Kaufmann dkk..$^{15}$ juga dinyatakan bahwa kejadian osteoporosis lebih tinggi pada pasien yang diberikan anastrozol dibanding dengan yang diberikan tamoksifen, meskipun angka kejadian fraktur adalah sama pada 2 kelompok. Namun dari hasil penelitian lainnya, yaitu penelitian Boccardo dkk. ${ }^{16}$ tidak terdapat perbedaan angka kejadian osteoporosis dan fraktur pada pasien yang diberikan anastrozol maupun tamoksifen.

Berdasarkan penelitian Szulc dan Delmas ${ }^{12}$ didapatkan hasil normal kadar $\beta$-Crosslaps pada pasien pascamenopause yang mendapat terapi hormonal adalah $<0,57 \mathrm{ng} / \mathrm{mL}$. Penelitian ini mendapatkan hasil bahwa kadar $\beta$-Crosslaps rata- rata pada kelompok pasien KPD yang diberikan anastrozol yaitu sebesar 0,488 . Hasil tersebut masih berada dalam batas nilai normal. Namun, ada 3 pasien yang kadar $\beta$-Crosslaps-nya di atas $0,57 \mathrm{ng} / \mathrm{mL}$. Hasil tersebut menandakan bahwa proses penyerapan tulang telah terjadi dan dapat memicu proses osteoporosis, bahkan fraktur di kemudian hari. Dengan demikian, untuk dapat mencegah osteoporosis sesuai dengan literatur dan penelitian sebelumnya, seperti penelitian van Poznak dkk. ${ }^{17}$ serta Eisen dkk. ${ }^{18}$ dinyatakan pasien yang telah diberikan anastrozol sebaiknya diberikan juga suplemen tambahan golongan bisfosfonat untuk meningkatkan densitas massa tulang.

Penelitian ini dilakukan dengan mengambil sampel dari pasien yang telah mempergunakan anastrozol maupun tamoksifen minimal selama 6 bulan, yaitu antara 6 bulan sampai 1 tahun. Goss dkk. ${ }^{8}$ yang meneliti penggunaan anastrozol pada wanita pascamenopause normal yang tidak menderita KPD dinyatakan bahwa kadar $\beta$-Crosslaps akan mulai terlihat peningkatannya setelah pemakaian 6 bulan.

Simpulan, terdapat perbedaan antara kadar $\beta$-Crosslaps serum pada KPD pascamenopause dan yang diberikan tamoksifen, yaitu kadar $\beta$ Crosslaps serum KPD yang diberikan anastrozol lebih tinggi dibanding dengan pasien KPD yang diberikan tamoksifen. Pemberian obat anastrozol pada pasien KPD pascamenopause dalam jangka waktu lebih dari 6 bulan meningkatkan proses penyerapan tulang bila dibanding dengan yang diberikan tamoksifen. ${ }^{19}$

\section{Daftar Pustaka}

1. Siegel R, Naishadham D, Jema A. Cancer statistics. Ca Cancer J Clin. 2013;63(1):1130.

2. Geisler J. Differences between the nonsteroidal inhibitor aromatases anastrozol and letrozole - of clinical importance. $\mathrm{Br} \mathrm{J}$ Cancer. 2011;104(7):1059-66.

3. Baum M, Buzdar A, Cuzick J, Forbes J, Houghton J, Howell A, dkk. Anastrozol alone or in combination with tamoksifen versus 
tamoksifen alone for adjuvant treatment of postmenopausal women with early-stage breast cancer. Cancer. 2003;98(9):1802-10.

4. Cuzick J. The ATAC trial: 10-year analysis. Proceedings of the $12^{\text {th }}$ Milan Breast Cancer Conference; 2010 Jun 16-18; London, Inggris. Italy; 2010.

5. Aydiner A, Tas F. Meta-analysis of trials comparing anastrozol and tamoksifen for adjuvant treatment of postmenopausal women with early breast cancer. Trials. 2008;9:47.

6. Howell A, Locker GY. Defining the roles of inhibitor aromatases in the adjuvant treatment of early-stage breast cancer. Clin Breast Cancer. 2005;6(4):302-9.

7. Eastell R, Hannon RA, Cuzick J, Dowsett M, Clack G, Adams JE, ATAC Trialists group. Effect of an inhibitor aromatase on bmd and bone turnover markers: 2-year results of the anastrozol, tamoxifen, alone or in combination (ATAC) trial. J Bone Miner Res. 2006;21(8):1215-23.

8. Goss PE, Hadji P, Subar M, Abreu P, Thomsen T, Banke-Bochita J. Effects of steroidal and nonsteroidal inhibitor aromatases on markers of bone turnover in healthy postmenopausal women. Breast Cancer Res. 2007;9(4):R52.

9. Lonning PE. Inhibitor aromatase in breast cancer. Endocr Relat Cancer. 2004;11:17989.

10. Dowsett M, Cuzick J, Ingle J, Coates A, Forbes J, Bliss J, dkk. Meta-analysis of breast cancer outcomes in adjuvant trials of inhibitor aromatases versus tamoxifen. J Clin Oncol. 2010;28(3):509-18.

11. Narashimamurty J, Rao AR, Sastry GN. Inhibitor aromatases: a new paradigm in breast cancer treatment. Curr Med Chem Anticancer Agents. 2004;4(6):523-34.

12. Szulc P, Delmas PD. Biochemical markers of bone turnover: potential use in the investigation and management of postmenopausal osteoporosis. Osteoporos Int. 2008;19(2):1683-704.

13. Cepelak I, Cvoriscec D. Biochemical markers of bone remodeling_review. Biochemica Medica. 2009;19(1):17-35.

14. Smith IE, Dowsett M. Inhibitor aromatases in breast cancer. N Engl J Med. 2003;348(24): 2431-42.

15. Kaufmann M, Jonat W, Hilfrich J, Eidtmann $H$, Gademann G, Zuna I, dkk. Improved overall survival in postmenopausal women with early breast cancer after anastrozol initiated after treatment with tamoxifen compared with continued tamoxifen: The ARNO 95 study. J Clin Oncol. 2007;25(19):2664-70.

16. Boccardo F, Rubagotti A, Puntoni M, Guglielmini P, Amoroso D, Fini A. Switching to anastrozol versus continued tamoxifen treatment of early breast cancer: preliminary results of the Italian Tamoxifen Anastrozol Trial. J Clin Oncol. 2005;23(22):5138-47.

17. Van Poznak CV, Hannon RA, Mackey JR, Campone M, Apffelstaedt JP, Clack G, dkk. Prevention of inhibitor aromatase-induced bone loss using risedronate: The SABRE trial. J Clin Oncol. 2010;28(6):967-75.

18. Eisen A, Trudeau M, Shelley W, Sinclair S, and the Breast Cancer Disease Site Group. The role of inhibitor aromatases in adjuvant therapy for postmenopausal women with hormone receptor-positive breast cancer: Guideline Recommendations. Evidencebased Series No:1-18. 2008. [diunduh 20 Juni 2013]. Tersedia dari: https://www. cancercare.on.ca/common/pages/UserFile. aspx?fileId=13882.

19. Petit T, Dufour P, Tannock I. A critical evaluation of the role of inhibitor aromatases as adjuvant therapy for postmenopausal women with breast cancer. Endocr Relat Cancer. 2011;18(3):79-89. 